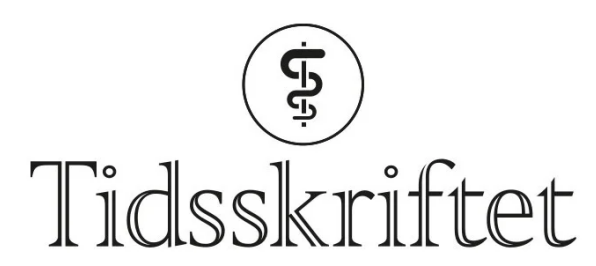

DEN NORSKE LEGEFORENING

\title{
Vaksinering mot svineinfluensa er trygt
}

NYHETER

ERLEND T. AASHEIM

Email: e.aasheim@imperial.ac.uk Imperial College London

\section{Sikkerheten ved vaksinering mot influensa $\mathrm{A}\left(\mathrm{H}_{1} \mathrm{~N}_{1}\right)$ var god, ifølge kinesiske forskere, som har oppsummert rapporterte bivirkninger etter 89,6 millioner vaksinedoser.}

Forekomsten av sjeldne, men alvorlige bivirkninger etter vaksinasjon kartlegges som oftest via passive meldesystemer. I en ny kinesisk studie er bivirkninger etter vaksinasjon mot pandemisk influensa $\mathrm{A}\left(\mathrm{H}_{1} \mathrm{~N}_{1}\right)$ oppsummert. I studien inngikk totalt 89,6 millioner doser kinesiskproduserte vaksiner gitt i perioden september 2009-mars 2010 (1).

Skoleelever, lærere, helsearbeidere og personer med kronisk sykdom var prioritert for vaksinasjon. De fleste rapporterte bivirkninger oppsto innen én dag etter vaksinasjonen. Rapporteringsfrekvensen var høyest i starten av vaksinekampanjen, i rike provinser, hos kvinner og hos yngre personer. Alvorlige bivirkninger ble rapportert ved åtte per en million vaksinedoser. Guillain-Barrés syndrom oppsto ved o,1 per en million doser, noe som ble angitt til å være lavere enn bakgrunnsforekomsten i Kina. Forfatterne konkluderte med at det ikke ble funnet noe mønster av bivirkninger som ga grunn til bekymring.

- Dette er en av de største studiene som noensinne er publisert om bivirkninger etter vaksinering, sier overlege Jann Storsæter og lege Ellen Furuseth ved Avdeling for vaksine, Folkehelseinstituttet.

- I studien benyttet man seg av et helt nytt system for nettbasert registrering av bivirkninger. Det var basert på retningslinjer fra WHO og omfattet hele Kina. Resultatene er sammenliknbare med funn fra andre studier som bygger på spontanrapportering. En svakhet med slike studier er imidlertid underrapportering. I denne studien forelå det bare ti rapporter om uventet dødsfall etter vaksinasjon, de fleste hos personer med hjertesykdom. Dette tallet virker lavt for en så stor gruppe personer, sier Storsæter og Furuseth. 
LITTERATUR

1. Liang XF, Li L, Liu DW et al. Safety of influenza A ( $\left.\mathrm{H}_{1} \mathrm{~N}_{1}\right)$ vaccine in postmarketing surveillance in China. N Engl J Med 2011; 364: 638-47.

Publisert: 6. mai 2011. Tidsskr Nor Legeforen. DOI: 10.4045/tidsskr.11.0268

(C) Tidsskrift for Den norske legeforening 2023. Lastet ned fra tidsskriftet.no 26. april 2023. 